\title{
IMPLEMENTASI PERATURAN DAERAH NOMOR 12 TAHUN 2005 TENTANG SERAH SIMPAN KARYA CETAK DAN KARYA REKAM DI BADAN PERPUSTAKAAN DAN ARSIP DAERAH PROVINSI D. I. YOGYAKARTA
}

\author{
Oleh : Prameswari Sekarningsih*
}

\begin{abstract}
District Regulation No. 12 Year 2005 is a juridical base that holds in Province of Yogyakarta Special Region, which regulates that publishers and record are obliged to submit their print or record works to the District Board of Library and Archives. The goal is create district is deposit collections industries and preserve them in order to be used continually both in present and future.

This study aims to find out the implementation of District Regulation No. 12 Year 2005 and what factors affecting District Regulation No. 12 Year 2005. This study used descriptive-qualitative method and the study is case study.

The study result showed that the District Board of Library and Archives has not been able yet to provide sufficient infrastructure, although it has carried out supporting events, such as socialization, "hunting", and symposium. To date, submission of print and record works to the District Board of Library and Archives has not been optimum. This is because there is no full awareness from publishers and record industries and there is no sanction applied based on the District Regulation.

Keywords: District Regulation Deposit, District Regulation No. 12 Local Rule of 2005, Implementation
\end{abstract}

*) Mahasiswa S2 MIPUGM

\section{A. PENDAHULUAN}

Perpustakaan sebagai pusat informasi mempunyai posisi yang sangat penting bagi keberhasilan studi bagi mahasiswa. Di Yogyakarta terdapat Badan Perpustakaan Dan Arsip Daerah yang merupakan Perpustakaan Umum yang terbentuk berdasarkan landasan Peraturan Daerah Provinsi D.I.Yogyakarta Nomor 7 Tahun 2008 tentang Organisasi dan Tatakerja Inspektorat, Badan Perencanaan Pembangunan Daerah, Lembaga Teknis Daerah dan Satuan Polisi Pamong Praja Provinsi D.I.Yogyakarta. Dalam peraturan tersebut Badan Perpustakaan dan Arsip Daerah adalah unsur pendukung tugas Kepala Daerah di bidang perpustakaan dan arsip, yang dipimpin oleh seorang Kepala yang berkedudukan di bawah dan bertanggungjawab kepada Gubernur melalui Sekretariat Daerah. Untuk menindaklanjuti Peraturan Daerah tersebut, perlu ditetapkan Peraturan Gubernur Nomor 54 Tahun 2008 tentang Rincian Tugas dan Fungsi Badan Perpustakaan Dan Arsip Daerah pada tanggal 12 Desember 2008.

Berdasarkan landasan yuridis tersebut, Badan Perpustakaan dan Arsip Daerah mempunyai tugas melaksanakan penyusunan dan pelaksanaan kebijakan daerah di bidang perpustakaan dan kearsipan. Dalam menjalankan tugas dan fungsinya, diperlukan pedoman yang berupa visi dan misi.

Mengingat dan memperhatikan Peraturan Daerah Provinsi Daerah Istimewa Yogyakarta Nomor 7 Tahun 2008, maka Badan Perpustakaan dan Arsip Daerah bertugas melaksanakan penyusunan dan pelaksanaan kebijakan daerah di bidang perpustakaan dan kearsipan. Selanjutnya Bidang Pengembangan Perpustakaan mempunyai tugas melaksanakan deposit, mengembangkan dan mengelola bahan pustaka serta membina, memberdayakan kelembagaan dan sumber daya manusia.

Dalam upaya melaksanakan tugas penerimaan dan pengelolaan karya cetak dan karya rekam, Bidang Pengembangan Perpustakaan yaitu Subbidang Deposit, berpedoman pada Peraturan Daerah Nomor 12 Tahun 2005 dan teknis pelaksanaannya diatur dengan Peraturan Gubernur Nomor 43 Tahun 2006. Pengundangan Peraturan Daerah ini dilakukan dengan menempatkannya dalam Lembaran Daerah Provinsi D.I. Yogyakarta Tahun 2005 Nomor 7 Seri E serta Berita Daerah Provinsi D.I. Yogyakarta Tahun 


\section{Nomor 44.}

Sebagaimana tersurat dalam pasal 3 demi kepentingan pendidikan, pengembangan ilmu pengetahuan dan teknologi, penelitian dan penyebarluasan informasi serta pelestarian hasil budaya daerah, setiap:

1. Penerbit yang berada di Daerah;

2. Pengusaha Rekaman yang berada di Daerah;

3. Warga Daerah yang hasil karyanya baik berupa karya rekam atau karya cetak yang diterbitkan/direkam baik di Luar Daerah maupun di Luar Negeri;

4. Orang atau Badan Usaha yang memasukkan karya cetak dan atau karya rekam mengenai Daerah baik dari luar daerah maupun luar negeri; wajib menyerahkan hasil karya cetak atau karya rekamnya kepada Badan Perpustakaan dan Arsip Daerah Provinsi D.I. Yogyakarta

Sedangkan materi yang harus diserahkan sesuai Peraturan Daerah Nomor 12 Tahun 2005 sesuai pasal 1 yaitu:

1. Karyà Cetak adalah semua jenis terbitan dari setiap karya intelektual dan/atau yang dicetak dan digandakan dalam bentuk buku, majalah, surat kabar, peta, brosur dan sejenisnya yang diperuntukan bagi umum;

2. Karya rekam adalah jenis rekaman dari setiap karya intelektual dan/ artistik yang direkam dan digandakan dalam bentuk pita, piringan, dan bentuk lain sesuai dengan perkembangan teknologi yang diperuntukkan bagi umum.

Sedangkan komponen penting dan peranannya dalam pelaksanaan Peraturan Daerah Nomor 12 Tahun 2005 adalah:

1. Penerbit/Pengusaha Rekaman yang berperan sebagai sasaran dari pelaksanaan Peraturan Daerah Nomor 12 Tahun 2005;

2. Badan Perpustakaan dan Arsip Daerah Provinsi D.I.Yogyakarta sebagai lembaga pelaksana Peraturan Daerah;

3. Penegak Hukum sebagai pengawas, pengaman serta menindak setiap pelanggaran terhadap pelaksanaan Peraturan Daerah.

Menurut Laporan Tahunan Badan Perpustakaan dan Arsip Daerah pada Tahun 2005-2008 karya cetak yang sudah diserahkan dan belum diserahkan terdapat pada tabel 1 dan tabel 2 berikut ini:

\section{Tabel 1}

Data Karya Cetak yang sudah diserahkan Tahun 2005-2008

\begin{tabular}{|c|c|c|}
\hline Tahun & $\begin{array}{c}\text { Penerimaan } \\
\text { karya cetak }\end{array}$ & Jumlah per tahun \\
\hline Tahun 2005 & 12.174 judul & - \\
\hline Tahun 2006 & 13.582 judul & 1.408 \\
\hline Tahun 2007 & 15.410 judul & 1.828 \\
\hline Tahun 2008 & 17.010 judul & 1.600 \\
\hline
\end{tabular}

Sumber Laporan Tahunan Badan Perpustakaan dan Arsip Daerah Tahun 2005-2008

Tabel 2

Data Karya Cetak yang belum diserahkan Tahun 2005-2008

\begin{tabular}{|l|l|}
\hline \multicolumn{1}{|c|}{ Jenis Karya Cetak } & \multicolumn{1}{c|}{ Jumlah } \\
\hline $\begin{array}{l}\text { Rata-rata karya cetak yang } \\
\text { sudah diserahkan pertahun }\end{array}$ & 1.612 judul \\
\hline $\begin{array}{l}\text { Penerbitan karya cetak Wilayah } \\
\text { D.I.Y pertahun }\end{array}$ & 15.000 judul*) \\
\hline $\begin{array}{l}\text { Karya cetak yang belum } \\
\text { diserahkan pert ahun }\end{array}$ & 13.388 judul \\
\hline
\end{tabular}

Sumber Laporan Tahunan Badan Perpustakaan Dan Arsip Daerah *) Sumber IKAPI

Data tersebut menunjukkan bahwa masih terdapat kendala dalam pelaksanaan dan hasil yang dicapai belum menunjukan hasil yang maksimal. Belum maksimalnya pelaksanaan Peraturan Daerah tersebut dapat dilihat dari: Pertama, hasil evaluasi yang dilakukan oleh Tim Koordinasi Pemantau Pelaksanaan Peraturan Daerah Nomor 12 Tahun 2005 menunjukkan bahwa hasil karya cetak dan karya rekam dari wajib serah masih rendah. Hal ini terbukti bahwa hasil penerimaan seluruh koleksi karya cetak dan karya rekam sampai dengan tahun 2008 dengan jumlah 17.010 judul (Laporan Tahunan Badan Perpustakaan dan Arsip Daerah: 2008). Kedua, banyak tersebarnya di berbagai tempat penerbit dan pengusaha rekaman di Wilayah D.I. Yogyakarta yang tidak tertib dalam mengirimkan setiap hasil terbitannya. Selain itu masih ada 
penerbit dan pengusaha rekaman yang belum mengetahui keberadaan Peraturan Daerah tersebut. Jumlah penerimaan tersebut lebih rendah dibandingkan jumlah terbitan buku di wilayah Yogyakarta, karena menurut IKAPI Cabang Yogyakarta, penerbitan buku Yogyakarta mencapai 15.000 judul pertahun.

Belum maksimalnya hasil penerimaan karya cetak dan karya rekam ini karena belum adanya kesadaran para wajib serah untuk menyerahkan setiap hasil terbitan dan produk rekamannya ke Badan Perpustakaan dan Arsip Daerah.

\section{Rumusan Masalah}

Pokok permasalahan tersebut dapat dirumuskan sebagai berikut:

1. Bagaimana implementasi Peraturan Daerah Nomor 12 Tahun 2005 di Badan Perpustakaan dan Arsip Daerah Provinsi D.I. Yogyakarta?

2. Faktor-faktor apa saja yang mempengaruhi implementasi Peraturan Daerah Nomor 12 Tahun 2005 Badan Perpustakaan dan Arsip Daerah Provinsi D.I. Yogyakarta?

\section{Tujuan dan Manfaat Penelitian}

Adapun tujuan dan manfaat yang ingin dicapai dalam penelitian adalah:

1. Untuk mengetahui implementasi Peraturan Daerah Nomor 12 Tahun 2005 Badan Perpustakaan dan Arsip Daerah Provinsi D.I. Yogyakarta.

2. Untuk mengetahui faktor-faktor apa saja yang mempengaruhi implementasi Peraturan Daerah Nomor 12 Tahun 2005 Badan Perpustakaan dan Arsip Daerah Provinsi D.I. Yogyakarta.

3. Memberikan masukan bagi lembaga pelaksana Serah Simpan Karya Cetak dan Karya Rekam di Indonesia dan sumbangan pengetahuan bagi perpustakaan.

\section{B. Landasan Teori}

Jenkins dalam Wikipedia Foundation Inc (2009) menjelaskan bahwa kebijakan adalah sekumpulan keputusan-keputusan yang saling berhubungan yang diambil oleh aktor politik atau kelompok actor mengenai pemilihan sasaran dan menempatkannya dalam suatu situasi yang ditetapkan dimana keputusan-keputusan itu berguna untuk mencapai tujuan yang diharapkan. Dalam hal ini kebijakan merupakan suatu proses, bukan hanya suatu pemilihan.

Udoji dalam Wahab (2005:59) menhatakan bahwa pelaksanaan kebijaksanaan adalah sesuatu yang penting darimana pembuatan-pembuatan kebijaksanaan. Kebijaksanaan-kebijaksanaan akan sekedar berupa impian atau rencana yang bagus yang tersimpan rapi dalam arsip kalau tidak diimplementasikan.

Menurut Abidin (2006: 189), proses pelaksanaan implementasi berkaitan dengan empat faktor utama, yaitu faktor utama internal yang meliputi kebijakan yang akan dilaksanakan dan factor-faktor pendukung. Untuk factor utama eksternal meliputi kondisi lingkungan dan pihakpihak terkait.

\section{Metode Penelitian}

Penelitian ini bertujuan untuk mengetahui Implementasi Peraturan Daerah Nomor 12 Tahun 2005 tentang Serah Simpan Karya Cetak dan Karya Rekam dan mengetahui faktor-faktor yang mempengaruhi implementasi aerah tersebut sejak berlakunya hingga sekarang. Metode penelitian yang digunakan dalam penelitian ini adalah metode penelitian diskriptif kualitatif.

Dengan melihat tujuan tersebut, maka desain penelitian yang digunakan adalah studi kasus.

Untuk mendapatkan data-data yang mendukung penelitian ini, peneliti melakukan dengan cara:

\section{a. Pengamatan}

Peneliti turun ke lapangan mengamati langsung terhadap kegiatan perpustakaan khususnya di Subbidang Deposit dan mencatat hasil 
pengamatan, serta secara langsung terhadap kegiatan-kegiatan di perpustakaan tersebut.

b. Wawancara/interview

Untuk mengetahui Implementasi Peraturan Daerah Nomor 12 Tahun 2005 dan faktorfaktor yang mempengaruhinya, maka dilakukan wawancara untuk memperoleh keterangan di lapangan dengan cara tanya jawab dan bertatap muka dengan informan.

Wawancara dilakukan dengan menggunakan panduan wawancara yang berisi butir-butir pertanyaan yang diajukan kepada informan, yang merupakan instrumen bagi peneliti untuk memudahkan dalam melakukan wawancara. Informan yang diwawancarai berjumlah 7 (tujuh) meliputi beberapa penerbit/pengusaha rekaman di wilayah D.I. Yogyakarta, Biro Hukum, Ikapi, dan Pelaksana Peraturan Daerah Nomor 12 tahun 2005. (Badan Perpustakaan dan Arsip Daerah).

c. Studi Dokumentasi

Studi dokumentasi mendukung data yang diperoleh di lapangan. Dokumentasi ini diambil dari data yang sudah tercatat baik berupa data deskriptif ataupun statistik yang berkaitan dengan penelitian. Data-data tersebut berdasarkan buku-buku yang berkaitan dengan masalah yang dibahas dan literatur-literatur, Peraturan Daerah, Petunjuk Teknis dan Petunjuk Pelaksanaan sebagai landasan dasar hukumnya.

\section{Isi Kebijakan Peraturan Daerah Nomor 12 Tahun 2005}

Keberhasilan implementasi Peraturan Daerah tidak lepas dari tepat atau tidaknya kebijakan yang diimplementasikan. Peran pemerintah dalam mewujudkan deposit daerah perlu mengeluarkan rekomendasi langkahlangkah yang harus ditempuh dan menetapkan suatu landasan hukum. Adapun kebijakan Deposit bahan pustaka ditingkat Provinsi dengan ditetapkan Peraturan Daerah tentang serah simpan karya cetak dan karya rekam. Peraturan Daerah ini sebagai dasar menjalankan tugas/penguatan yuridis untuk melaksanakan serah simpan karya cetak dan karya rekam.

Sub bidang Deposit merupakan bagian dari Bidang Pengembangan Perpustakaan mempunyai tugas menerima dan mengelola karya cetak karya rekam serta mengembangkan dan mengelola bahan pustaka. Untuk melaksanakan tugas tersebut Subbidang Deposit mempunyai fungsi antara lain pencarian, pemantauan, dan pendayagunaan karya cetak dan karya rekam.

\section{E. Mekanisme Penyerahan Cetakan/ Rekaman}

1. Pihak/lembaga yang wajib menyerahkan karya cetak dan karya rekam

Pihak-pihak yang wajib menyerahkan karya cetak dan karya rekam kepada Badan Perpustakaan dan Arsip Daerah adalah sebagai berikut:
a. Penerbit yang berada di daerah;
b. Pengusaha Rekaman yang berada di daerah;
c. Warga daerah;
d. Orang atau Badan Usaha.

2. Karya cetak dan karya rekam yang wajib diserahkan

Karya cetak dan karya rekam yang wajib diserahkan kepada Badan Perpustakaan dan Arsip Daerah oleh para penerbit dan pengusaha rekaman adalah sebagai berikut:
a. Karya cetak;
b. Karya rekam;
c. Daftar Judul.
Di samping karya cetak dan karya rekam, pihak wajib serah diharuskan pula menyerahkan daftar judul karya cetak dan karya rekamnya, juga berlaku bagi rekaman cerita dan dokumenter selambat-lambatnya 6 (enam) bulan sekali. Penyerahan daftar judul tersebut berlaku juga bagi setiap Warga 


\section{KATA PENGANTAR}

Puji syukur dipanjatkan kehadirat Allah SWT karena dengan limpahan rahmat dan hidayah-Nya, Media Informasi dapat hadir dihadapan pembaca yang budiman. Ternyata mencari naskah penelitian yang "layak terbit" tidak semudah yang dibayangkan. Apalagi untuk memenuhi kriteria yang diinginkan Redaksi, namun demikian Redaksi tetap berusaha mendapatkan naskah dengan sistem "jemput bola" khususnya kepada mahasiswa S1, S2, dan pustakawan yang telah melakukan penelitian. Semua itu dimaksudkan supaya Berkala Ilmu Perpustakaan dan Informasi dapat hadir di hadapan pembaca.

Dalam edisi kali ini naskah berasal dari mahasiswa S2 MIP UGM yang telah melakukan penelitian. Salah satu fungsi perpustakaan adalah menyimpan semua karya cetak dan karya rekam yang sering disebut fungsi deposit. Sdr. Prameswari Sekarningsih mengupas tentang tentang bagaimana implementasi Peraturan Daerah No.12 Tahun 2005 tentang Serah Simpan Karya Cetak dan Karya Rekam di Badan Perpustakaan dan Arsip Daerah Propinsi DIY.

Kemudian Milawati mengamati tentang perpustakaan umum yang mempunyai peran strategis untuk meningkatkan ilmu pengetahuan masyarakat. Strategi apa - saja yang dapat digunakan sehingga perpustakaan umum dapat dimanfaatkan oleh masyarakat yang belum mempunyai budaya baca yang tinggi.

Penelitian menarik yang tidak pernah mendapat perhatian adalah tentang diseminasi informasi pertanahan melalui kelompok masyarakat dalam pensertifikatan tanah di Kabupaten Bantul. Ternyata informasi bermanfaat untuk menghasilkan sertifikat tanah yang menjadi bukti secara hukum atas kepemilikan sebidang tanah. Diseminasi informasi ini dimaksudkan agar masyarakat dapat mengurus sertifikat tanah sendiri tanpa melalui perantara.

Penelitian tentang pelayanan masih menjadi topik yang menarik sepanjang zaman karena untuk mengimbangi tunt utan pemustaka yang semakin beragam dan banak seiring dengan perkembangan ilmu pengetahuan dan teknologi. Sdr. Yuslinah Nurdiyani membahas tentang pelayanan yang dilakukan UPT Perpustakaan Universitas Khairun Ternate (Unkhair)

Akhirnya, selamat membaca artikel-artikel yang kami sajikan, semoga bermanfaat dan dapat menambah pengetahuan para pembaca. Amin

Salam dari Redaksi 
Daerah yang memasukan karya cetak dan atau karya rekam mengenai Daerah.

\section{Waktu Penyerahan}

Bagi para Penerbit dan Pengusaha Rekaman yang menghasilkan karya cetak dan karya rekam, wajib menyerahkan hasil karyanya kepada Badan Perpustakaan dan Arsip Daerah selambat-lambatnya 3 (tiga) bulan setelah diterbitkan.

4. Cara Penyerahan

Penyerahan karya cetak dan karya rekam dapat diantar langsung atau melalui pos, dengan alamat Badan Perpustakaan Dan Arsip Daerah JL. Tentara Rakyat Mataram No. 29 Yogyakarta Telepon (0274) 513969, 561218.

\section{F. Realisasi yang di capai}

Kegiatan yang dilakukan Badan Perpustàkaan dan Arsip Daerah sebagai pelaksana Peraturan Daerah tentang serah simpan karya cetak dan karya rekam mempunyai tujuan untuk mewujudkan koleksi deposit daerah dan pelestariannya. Badan Perpustakaan dan Arsip Daerah harus mempersiapkan infrastruktur yang memadai untuk mendukung pelaksanaan tugas tersebut. Selanjutnya agar Peraturan Daerah dapat diketahui oleh masyarakat, Badan Perpustakaan dan Arsip Daerah melaksanakan sosialisasi melalui penyebarluasan Peraturan Daerah ke berbagai instansi, khususnya kepada pihak wajib serah simpan karya cetak dan karya rekam di Wilayah D.I. Yogyakarta, yaitu ke berbagai penerbit dan pengusaha rekaman baik swasta maupun pemerintah. Tujuan sosialisasi ini agar masyarakat setempat ataupun penerbit dan pengusaha rekaman mengerti makna dan cakupan Peraturan Daerah, selain itu juga mengadakan sosialisasi, sarasehan dengan penerbit dan pengusaha rekaman. Selanjutnya, sebagaimana tercakup dalam Peraturan Daerah tersebut, Badan Perpustakaan dan Arsip Daerah mempunyai tugas menyimpan, kemudian melestarikan dan mendayagunakan sesuai peraturan perundangan yang berlaku. Semua tugas tersebut sampai saat ini telah dilaksanakan Subbidang Deposit. Disamping itu, untuk menghimpun karya cetak dan karya rekam, Badan Perpustakaan dan Arsip Daerah mengadakan hunting kepada pihak wajib serah untuk mendapatkan terbitan-terbitan yang telah diterbitkan oleh penerbit swasta maupun pemerintah. Selanjutnya, karya cetak dan karya rekam dari pihak wajib serah yang telah diterima dan terkumpul kemudian dikelola oleh Badan Perpustakaan dan Arsip Daerah.

Mengacu pada Peraturan Daerah, selain mempunyai hak untuk menerima dan mengelola hasil penerimaan seluruh karya cetak dan karya rekam yang diserahkan, Badan Perpustakaan dan Arsip Daerah juga mempunyai kewajiban menyusun Bibliografi Daerah yang harus disampaikan kepada penerbit dan pengusaha rekaman yang telah menyerahkan karya cetak dan karya rekam dan atau Badan yang ada kaitannya dengan penyebaran informasi.

Kewajiban selanjutnya yang harus dilakukan oleh Badan Perpustakaan Dan Arsip Daerah adalah melestarikan sesuai dengan tujuan dari kewajiban serah simpan tersebut agar tujuan untuk mewujudkan aset daerah dan pelestariannya dapat tercapai. Pada saat ini untuk melakukan pelestarian hasil serah simpan dari pihak wajib serah, Subbidang Deposit menyerahkan pada Bidang Pelestarian. Sampai saat ini kegiatan pelestarian yang dilakukan baru sebatas bentuk fisik asli bahan pustaka seperti penjilidan dan penyampulan. Sedangkan proses alih media ke dalam bentuk mikrofilm atau bentuk lainnya seperti CD-ROM sampai saat ini belum pernah dilakukan untuk koleksi deposit, dengan alasan belum mendesak dan koleksinya mudah dicari, maka kegiatan tersebut sampai saat ini belum bisa dilakukan.

Selanjutnya kewajiban lain yang harus dilaksanakan oleh Badan Perpustakaan dan Arsip Daerah adalah melakukan pendayagunaan karya cetak dan karya rekam yang telah diserahkan oleh pihak wajib serah. Koleksi tersebut dapat 
dipinjamkan dalam arti untuk dibaca ditempat, dan tidak dapat dibawa pulang, baik oleh masyarakat pengguna maupun oleh karyawan Badan Perpustakaan dan Arsip Daerah.

Selain kegiatan-kegiatan di atas, dalam implementasi Peraturan Daerah, Subbidang Deposit telah melakukan kegiatan-kegiatan penunjang tugasnya. Adapun kegiatan-kegiatan pengelolaan karya cetak dan karya rekam agar Peraturan Daerah ini dapat diketahui secara luas, maka telah diadakan kegiatan-kegiatan:

Pemasyarakatan karya cetak dan karya rekam kepada seluruh penerbit yang dapat dijaring oleh Tim Sosialisasi;

1. Penggandaan Peraturan Daerah untuk disebarluaskan kepada pihak penerbit dan pengusaha rekaman baik swasta maupun pemerintah;

2. Sarasehan tentang pelaksanaan Peraturan Daerah;

3. Pembentukan Tim Pemantau/Pencarian terbitan/rekaman (Tim Hunting) guna memantau terbitan yang telah dan akan diedarkan di Wilayah D.I.Yogyakarta;

4. Menjalin hubungan silaturahmi dengan para penerbit secara berkala;

5. Menjalin hubungan kerjasama dengan tokotoko buku;

6. Menjalin hubungan dengan asosiasi Penerbit di D.I. Yogyakarta (IKAPI DIY);

7. Menyusun Bibliografi Daerah sebagai pertanggungjawaban penerima;

8. Evaluasi terhadap pelaksanaan serah simpan karya cetak dan karya rekam.

Demi kelancaran tugas tersebut diperlukan Pembentukan Tim Koordinasi yang bertujuan agar peredaran karya cetak dan karya rekam di Wilayah D.I. Yogyakarta dapat dipantau. Untuk mencapai tujuan ini, Badan Perpustakaan dan Arsip Daerah membentuk Tim Koordinasi yang terdiri dari beberapa orang yang berasal dari Badan Perpustakaan dan Arsip Daerah, Kepolisian, Kejaksaan Tinggi, Kantor Wilayah Departemen Kehakiman dan HAM, Biro Hukum
Sekretariat Daerah, Penyidik Pegawai Negeri, Organisasi Profesi terkait yang ada di Provinsi D.I. Yogyakarta. Tim Koordinasi tersebut dibentuk untuk membantu Kepala Badan Perpustakaan dan Arsip Daerah dalam pemantauan pelaksanaan Peraturan Daerah tersebut yang meliputi ketaatan terhadap karya rekam, menjelaskan Peraturan Daerah, menanyakan sudah melaksanakan wajib serah dan menyerahkan daftar katalog buku atau belum. Selain itu sosialisasi juga dilakukan dengan cara memberikan penghargaan kepada penerbit dan pengusaha rekaman yang tertib melaksanakan serah simpan karja cetak dan karya rekam.

Sampai saat ini koordinasi dan kerjasama yang dilakukan dalam Tim Koordinasi sudah berjalan lancar, tetapi masih perlu ditingkatkan lagi. Hal ini berarti bahwa kegiatan yang dilakukan oleh Tim Koordinasi adalah memantau pelaksanaan Peraturan Daerah untuk mendapatkan data-data terbitan di pasaran dan untuk mengetahui karya cetak dan karya rekam yang belum diserahkan oleh Penerbit atau Pengusaha Rekaman.

Sedang untuk kegiatan sosialisasi ditujukan kepada para penerbit dan pengusaha rekaman di Wilayah D.I. Yogyakarta, yaitu Penerbit dan Pengusaha Rekaman yang telah menjadi anggota Ikapi maupun yang bukan anggota Ikapi. Prioritas kegiatan ini terutama sekali ditujukan kepada pihak wajib serah yang belum menget ahui keberadaan Peraturan Daerah yang tidak tertib melaksanakan kewajibannya. Sedangkan proses sanksi pidana sampai sekarang belum pernah dilaksanakan oleh Badan Perpustakaan dan Arsip Daerah, karena pihak wajib serah apabila ditegur/diingatkan langsung memenuhi kewajibannya.

1. Untuk mengetahui hasil yang telah dicapai diadakan evaluasi terhadap kegiatan yang telah dilaksanakan. Tujuan dari kegiatan evaluasi tersebut antara lain sebagai berikut:

2. Untuk mengetahui sejauh mana Badan Perpustakaan dan Arsip Daerah telah 
melaksanakan Peraturan Daerah;

3. Untuk mengetahui kendala yang dihadapi Badan Perpustakaan dan Arsip Daerah dalam melaksanakan Peraturan Daerah tersebut; '

4. Untuk mengetahui jumlah Penerbit dan Pengusaha Rekaman yang ada di Wilayah D.I. Yogyakarta yang telah melaksanakan kewajibannya;

5. Untuk mengetahui kondisi pihak wajib serah dilihat dari jumlah produksi yang dihasilkan setiap tahun;

6. Untuk memberikan masukan bagi Badan Perpustakaan dan Arsip Daerah guna meningkatkan kualitas pelaksanaan serah simpan karya cetak dan karya rekam.

\section{G. Penyimpangan yang terjadi pada Pelaksanaan Peraturan Daerah Nomor 12 Tahun 2005}

Adapun temuan penyimpangan tersebut pertama, Badan Perpustakaan dan Arsip Daerah belum berani mewajibkan kepada pengusaha rekaman untuk menyerahkan produk rekamannya karena kesulitan sarana dan prasarana dalam penyimpannya termasuk warga daerah, orang/badan usaha sesuai amanat pasal 3; kedua, belum dilaksanakan sanksi dan denda bagi bagi penerbit dan pengusaha rekaman yang melanggar Peraturan Daerah tersebut; ketiga, adanya penerapan pola kemitraan antara Badan Perpustakaan dan Arsip Daerah dan penerbit /pengusaha rekaman membuat pelaksanaan sanksi dan denda lemah. Penyimpangan lain adalah masih ada dari pihak wajib serah yang belum mempunyai kesadaran untuk menyerahkan terbitan maupun rekamannya. Sedang penyimpangan dari penegak hukum antara lain penerapan sanksi belum terlaksana. Adapun alasannya karena belum adanya laporan pelanggaran dari pelaksana Peraturan Daerah. Berkaitan dengan penyimpangan pihak instansi terkait khususnya Ikapi sebagai wadah Penerbit antara lain belum dapat mengakomodir seluruh penerbit yang ada di Wilayah D. I. Yogyakarta menjadi anggota Ikapi.

\section{H. Kendala-Kendala Yang Muncul Dalam Implementasi Peraturan Daerah Nomor 12 Tahun 2005}

1. Badan Perpustakaan dan Arsip Daerah

a. Dalam implementasi pelaksanaan Peraturan Daerah, Badan Perpustakaan dan Arsip Daerah sampai saat ini masih belum siap karena:

b. Badan Perpustakaan dan Arsip Daerah belum mempersiapkan infrastruktur-nya antara lain tempat/gedung, sarana dan prasarana, sumber daya manusia, serta anggaran yang memadai;

c. Luas Wilayah D.I. Yogyakarta yang tediri dari 4 (empat) Kabupaten dan 1 (satu) Provinsi tidak sebanding dengan jumlah petugas pemantau pelaksana Peraturan Daerah, sehingga menimbulkan kesulitan dalam koordinasi;

d. Tidak semua Penerbit menjadi anggota organisasi profesi seperti Ikapi;

e. Kompleknya kondisi dari pihak wajib serah karya cetak dan karya rekam, misalnya terdapat penerbit yang sudah gulung tikar, penerbit yang beralih profesi lain, beberapa penerbit yang tidak menetap/kontrak dan sulit pelacakannya, sehingga sulit bagi Badan Perpustakaan dan Arsip Daerah dalam pendataannya;

f. Sulitnya melakukan pendataan karya cetak dan karya rekam yang telah disebarluaskan di pasaran;

Sampai saat ini Badan Perpustakaan dan Arsip Daerah masih menetapkan pola kemitraan, dimana penerbit dan pengusaha rekaman itu menjadi mitra kerja Badan Perpustakaan dan Arsip Daerah, sehingga lemah dalam penerapanan sanksi dan denda;

Kurangnya kesadaran para penerbit dan pengusaha rekaman dalam memenuhi kewajiban Peraturan Daerah, hal ini terlihat dari kenyataan di lapangan, yaitu walaupun 
sudah banyak penerbit dan pengusaha rekaman yang tahu tentang Peraturan Daerah tersebut, namun masih banyak para wajib serah yang tidak tertib menyerahkan terbitan/produknya, sesuai batas waktu penyerahan yang ditentukan dalam Peraturan Daerah tersebut.

2 Penerbit dan Pengusaha Rekaman

Kendala dari penerbit dan pengusaha rekaman antara lain tidak ada yang menangani arsip dan pengiriman terbitan/rekamannya, termasuk kesulitan sumber dana dan sumber daya, sedang pengusaha rekaman biasanya memiliki 1 arsip untuk Perusahaan.

3. Penegak Hukum

Pelaksanaan Peraturan Daerah dapat efektif, apabila dalam pelaksanaan dilengkapi dengan penerapan sanksi bagi penerbit dan pengusaha rekaman yang melanggar. Dengan demikian agar penerapan sanksi dapat terlaksana, maka penegak hukum merupakan aktor yang berfungsi sebagai pengawas, pengaman, serta menindak setiap pelanggaran sesuai Peraturan Daerah.

4. Instansi Terkait

Implementasi Peraturan Daerah tersebut tidak dapat dilepaskan dari peranan instansi terkait yaitu induk organisasi/asosiasi penerbit dan pengusaha rekaman, seperti Ikatan Penerbit Indonesia (IKAPI), SPS, dan lain-lain.

\section{Upaya Pemecahan Masalah}

1. Badan Perpustakaan dan Arsip Daerah

Upaya untuk mengatasi kendala tersebut adalah bersama Tim Koordinasi membentuk Tim Pemantauan, dan mengadakan sosialisasi, sarasehan serta hunting. Selain itu juga upaya yang harus dilakukan oleh Badan Perpustakaan dan Arsip Daerah meningkatkan sumber daya manusia dengan memberi tugas sehari-hari untuk melaksanakan Peraturan Daerah, memiliki gedung/ruangan serta sarana prasarana penunjang. Pemantauan dilakukan dengan menghimbau/mengingatkan kepada pihak wajib serah untuk melaksanakan kewajibannya sesuai Peraturan Daerah

2. Penerbit dan Pengusaha Rekaman

Adapun upaya dalam mengatasi masalah dari Penerbit dan Pengusaha Rekaman dalam implementasi Peraturan Daerah adalah pihak Badan Perpustakaan dan Arsip Daerah bersikap pro aktif, dengan jemput bola yaitu langsung mendatangi penerbit yang tidak aktif, terus menerus mensosialisasikan Peraturan Daerah itu, dan mengingatkan serta menanyakan buku-buku yang belum diserahkan. Dengan demikian penerbit dan pengusaha rekaman memiliki kesadaran untuk menyerahkan terbitan atau rekamannya.

3. Penegak Hukum

Dengan mengingat amanah Peraturan Daerah yang harus dilaksanakan dengan tertib oleh pihak wajib serah, maka Peraturan Daerah harus terus menerus disosialisasikan. Pihak wajib serah yang melanggar Peraturan Daerah harus diberi sanksi dan denda.

4. Instansi Terkait

Dengan demikian Badan Perpustakaan dan Arsip Daerah sendiri harus dipersiapkan gedung/tempat yang memenuhi standar persyaratan penyimpanan. Dengan terus mensosialisasikan, menghimbau, mengingatkan, dengan mendatangi penerbit dan pengusaha rekaman, maka penerimaan deposit akan meningkat. Sesuai harapan penerbit dan pengusaha rekaman untuk pemecahan masalah antara lain mempromosikan buku-buku baru penerbit dan produk rekamannya dalam website.

\section{J. Temuan Dalam Implementasi Peraturan Daerah Nomor 12 Tahun 2005}

Berdasarkan hasil penelitian, dalam implementasi Peraturan Daerah tentang serah 
simpan karya cetak dan karya rekam dari awal pelaksanaannya sampai sekarang, diperoleh beberapa temuan dalam pelaksanaanya. Adapun temuan-temuan tersebut dapat dipaparkan sebagai berikut:

\section{Kebijakan}

Nama Badan Perpustakaan dan Arsip Daerah tidak sesuai dengan kondisi yang sekarang, karena adanya perubahan nama dan penggabungan dengan instansi lain. Hal ini tentu akan berdampak pada pelaksanaan pasal-pasal dan ayat yang menyangkut Badan Perpustakaan dan Arsip Daerah.

Selain itu, pengusaha rekaman berpendapat bahwa Badan Perpustakaan dan Arsip Daerah belum memiliki tempat penyimpanan khusus karya rekam yang memenuhi syarat. Pengusaha rekaman belum dapat mempercayakan hasil produk rekamannya untuk disimpan di Badan Perpustakaan dan Arsip Daerah. Dengan melihat masalah-masalah dalam substansi Peraturan Daerah, maka Peraturan Daerah tersebut harus segera direvisi, karena berdampak pada pasal dan ayat-ayatnya serta penghambat keberhasilan implementasi Peraturan Daerah di Badan Perpustakaan dan Arsip Daerah pasal dan ayatayatnya serta penghambat keberhasilan implementasi Peraturan Daerah di Badan Perpustakaan Dan Arsip Daerah.

\section{Implementasi Peraturan Daerah Nomor 12} Tahun 2005

Implementasi Peraturan Daerah hampir berjalan 4 tahun yaitu sejak diberlakukannya dari tahun 2005 sampai sekarang. Perkembangan Implementasi Peraturan Daerah tersebut tidak dapat dilepaskan dari peranan aktor-aktor yang terlibat aktif dalam implementasi tersebut.

Langkah-langkah yang dilakukan oleh Badan Perpustakaan dan Arsip Daerah dalam pengumpulan karya cetak dan karya rekam adalah sebagai berikut:

a. Menyusun daftar pihak wajib serah karya cetak dan karya rekam yang secara terus menerus disempurnakan untuk dipergunakan pedoman tugas sehari-hari;

b. Mengirimkan landasan hukum Peraturan Daerah dan Peraturan Gubernur tentang kewajiban serah simpan karya cetak dan karya rekam kepada pihak wajib serah;

c. Mengadakan pendekatan kepada semua pimpinan lembaga pemerintah untuk mendukung penyerahan karya cetak dan karya rekam.

Berdasarkan hasil penelitian terhadap implementasi Peraturan Daerah tersebut ternyata masih terdapat banyak faktor penghambat dalam pelaksanaan Peraturan Daerah dari awal pelaksanaan sampai sekarang, yaitu:

a. Ketertiban dari pihak wajib serah masih belum maksimal. Hal ini disebabkan karena adanya masalah manajermen yang belum bagus di dalam perusahaan, khususnya yang beromset kecil, ditinjau dari sumber daya dan sumber dana yang kurang memadai;

b. Badan Perpustakaan dan Arsip Daerah belum mampu menyediakan infrastruktur yang memadai seperti gedung, sumber daya manusia, sarana dan prasarana serta anggaran untuk mengelola hasil serah simpan karya cetak dan karya rekam. Dengan demikian, maka kesadaran mengenai hal tersebut harus ada dari kedua belah pihak.

3. Faktor-Faktor Yang Mempengaruhi Implementasi Peraturan Daerah Nomor 12 Tahun 2005

Dengan melihat permasalahan dan upaya pemecahan masalah yang dipaparkan pada bab terdahulu, maka dapat diketahui faktor-faktor yang mempengaruhi implementasi Peraturan Daerah.

Menurut Sumaryadi (2005: 81), secara sederhana keberhasilan implementasi dapat dilihat dari dua sisi, yaitu:

a. Sisi keberhasilan dalam mencapai tujuan (sasaran), meliputi Penerbit Daerah, 